\title{
Vitamin D inadequacy in Belgian postmenopausal osteoporotic women
}

\author{
Audrey Neuprez ${ }^{\dagger}$, Olivier Bruyère ${ }^{* \dagger}$, Julien Collette ${ }^{\dagger}$ and Jean-Yves Reginster ${ }^{\dagger}$
}

Address: Department of Epidemiology, Public Health and Health Economics, University of Liege, 4020 Liege, Belgium

Email: Audrey Neuprez - Audrey.Neuprez@student.ulg.ac.be; Olivier Bruyère* - Olivier.Bruyere@ulg.ac.be;

Julien Collette - j.collette@chu.ulg.ac.be; Jean-Yves Reginster - jyreginster@ulg.ac.be

* Corresponding author †Equal contributors

Published: 26 April 2007

BMC Public Health 2007, 7:64 doi:10.1 I86/147|-2458-7-64

This article is available from: http://www.biomedcentral.com/I47/-2458/7/64

(C) 2007 Neuprez et al; licensee BioMed Central Ltd.

This is an Open Access article distributed under the terms of the Creative Commons Attribution License (http://creativecommons.org/licenses/by/2.0), which permits unrestricted use, distribution, and reproduction in any medium, provided the original work is properly cited.
Received: 25 October 2006

Accepted: 26 April 2007

\begin{abstract}
Background: Inadequate serum vitamin D [25(OH)D] concentrations are associated with secondary hyperparathyroidism, increased bone turnover and bone loss, which increase fracture risk. The objective of this study is to assess the prevalence of inadequate serum $25(\mathrm{OH}) \mathrm{D}$ concentrations in postmenopausal Belgian women. Opinions with regard to the definition of vitamin $D$ deficiency and adequate vitamin $D$ status vary widely and there are no clear international agreements on what constitute adequate concentrations of vitamin $D$.
\end{abstract}

Methods: Assessment of 25-hydroxyvitamin D [25(OH)D] and parathyroid hormone was performed in 1195 Belgian postmenopausal women aged over 50 years. Main analysis has been performed in the whole study population and according to the previous use of vitamin $D$ and calcium supplements. Four cut-offs of $25(\mathrm{OH}) \mathrm{D}$ inadequacy were fixed : $<80 \mathrm{nmol} / \mathrm{L},<75 \mathrm{nmol} / \mathrm{L}$, $<50 \mathrm{nmol} / \mathrm{L}$ and $<30 \mathrm{nmol} / \mathrm{L}$.

Results: Mean (SD) age of the patients was $76.9(7.5)$ years, body mass index was $25.7(4.5) \mathrm{kg} /$ $\mathrm{m}^{2}$. Concentrations of $25(\mathrm{OH}) \mathrm{D}$ were $52.5(2 \mathrm{I} .4) \mathrm{nmol} / \mathrm{L}$. In the whole study population, the prevalence of $25(\mathrm{OH}) \mathrm{D}$ inadequacy was $91.3 \%, 87.5 \%, 43.1 \%$ and $15.9 \%$ when considering cutoffs of $80,75,50$ and $30 \mathrm{nmol} / \mathrm{L}$, respectively. Women who used vitamin $\mathrm{D}$ supplements, alone or combined with calcium supplements, had higher concentrations of $25(\mathrm{OH}) \mathrm{D}$ than non-users. Significant inverse correlations were found between age/serum PTH and serum 25(OH)D $(r=-$ $0.23 / r=-0.3 \mathrm{I})$ and also between age/serum PTH and femoral neck BMD $(r=-0.29 / r=-0.15)$. There is a significant positive relation between age and PTH $(r=0.16)$, serum $25(\mathrm{OH}) \mathrm{D}$ and femoral neck BMD $(r=0.07) .(P<0.05)$

Vitamin $D$ concentrations varied with the season of sampling but did not reach statistical significance $(P=0.09)$.

Conclusion: This study points out a high prevalence of vitamin $D$ inadequacy in Belgian postmenopausal osteoporotic women, even among subjects receiving vitamin $D$ supplements. 


\section{Background}

Osteoporosis is a chronic, progressive disease characterized by reduced bone mass and microarchitectural deterioration of bone, involving an extensive fragility and a subsequent increase in fracture risk [1].

Vitamin D and calcium are essential components of osteoporosis management. Once vitamin D is absorbed from the diet or synthetised in the skin by the action of sunlight, it is metabolized first in liver to 25-hydroxyvitamin $\mathrm{D}[25(\mathrm{OH}) \mathrm{D}]$ and then in kidney to 1,25-dihydroxyvitamin D $[1,25(\mathrm{OH}) 2 \mathrm{D}]$, before becoming biologically active. Then, 1,25(OH)2D interacts with its nuclear receptor (VDR) in target tissues where appropriate biological responses are mediated, in particular to maintain calcium homeostasis by increasing efficiency of intestinal calcium absorption [2]. As a consequence, decreasing 25(OH)D serum concentrations leads to reduced calcium absorptive performance yielding to an increase in PTH concentrations [3]. This leads to an increased bone resorption and accelerated bone loss, by increasing the number and activity of osteoclasts that release calcium from bone. Decreasing bone mineral density (BMD) and bone strength with increased susceptibility to fragility-fracture risk are ultimate consequences of vitamin D deprivation [4-6]. Vitamin $\mathrm{D}$ inadequacy has also been implicated as a contributing factor to muscle weakness and propensity to fall, both in active and inactive ambulatory elderly subjects $[7,8]$. A positive relationship has also been shown between cognitive functioning and vitamin $\mathrm{D}$ concentrations, which may also influence the risk of fall and fracture [9].

Sunlight and diet are the two sources of vitamin D. UV-B irradiation is the primary source of vitamin D. Approximately $90 \%$ of serum vitamin D is produced endogenously from 7-dehydrocholesterol in the epidermis of the skin, after adequate exposure. However, the capacity of the skin to produce vitamin $\mathrm{D}$ declines with aging $[4,10,11]$. Moreover, environmental factors influence the cutaneous production of vitamin D. Latitude, season, and time of day as well as ozone pollution in the atmosphere diversify the number of solar ultraviolet B photons reaching the earth's surface, and thereby, alter the cutaneous production of vitamin D3 [12].

As a consequence, in the light of the implication of vitamin D deficiency in bone metabolism, osteoporosis prevention guidelines developed by scientific authorities contain recommendations for vitamin D intake and evidence-based treatment of osteoporosis requires vitamin $\mathrm{D}$ supplements to maintain adequate plasma concentration [13-15].
The objective of this study is to assess the prevalence of inadequate serum vitamin D concentrations in postmenopausal Belgian women.

\section{Methods}

Belgian postmenopausal women aged over 50 years were included in the study ( $\mathrm{n}=1195)$, of which overall $52.5 \%$ had a prior fragility fracture. These women were part of a run-in study aimed at normalizing the calcium and vitamin D status of patients prior to be included in a trial, investigating the anti-fracture efficacy of a new anti-osteoporotic drug. Women were eligible for this study if they had been postmenopausal for at least five years, with at least one fracture confirmed by spinal radiography or a lumbar-spine bone mineral density $(\mathrm{BMD}) \leq 0.840 \mathrm{~g} / \mathrm{cm}^{2}$ or a femoral neck BMD $\leq 0.600 \mathrm{~g} / \mathrm{cm}^{2}$. Among the women included in this study, $26.4 \%$ already received vitamin D supplements (vitamin D3) and $45.4 \%$ got calcium supplementation.

After receiving information from the investigator, and being able to ask questions regarding all aspects of the study, all participants provided written informed consent before enrolment; the study was approved by the Institutional Review Board of the University of Liège, BELGIUM.

Fasting blood and urine samples were collected at baseline, stored at $-80^{\circ} \mathrm{C}$ and centrally analyzed. Assessment of 25-hydroxyvitamin D [25(OH)D] was performed with a commercial radioimmunoassay [DiaSorin (formerly Incstar Corporation), Stillwater, Minnesota, USA]. It consists of a two-step procedure. In a first step, the $25(\mathrm{OH}) \mathrm{D}$ and other hydroxylated metabolites are rapidly extracted from serum or plasma with acetonitrile. The extract is then assayed by RIA using a polyclonal antibody with specificity to $25(\mathrm{OH}) \mathrm{D}$. The sample, the antibody and the tracer are incubated for 90 minutes at room temperature (20$25^{\circ} \mathrm{C}$ ). The complexes "antigen-antibody» are separated after 20 minutes incubation at RT with a second antibody precipitating complex. This radioimmunoassay is a competitive binding assay with a limit of detection of $4 \mathrm{ng} / \mathrm{ml}$ and a within and between assay precision lower than $8 \%$.

In this particular study, four cut-offs of 25(OH)D inadequacy were fixed : $<80 \mathrm{nmol} / \mathrm{L}$ (mild deficiency), $<75$ $\mathrm{nmol} / \mathrm{L}$ (moderate deficiency), $<50 \mathrm{nmol} / \mathrm{L}$ (severe deficiency) and $<30 \mathrm{nmol} / \mathrm{L}$ (very severe deficiency). The laboratory performing the $25(\mathrm{OH}) \mathrm{D}$ assessment take part in a $25(\mathrm{OH}) \mathrm{D}$ quality scheme such as the International Quality Assessment Scheme for Vitamin D metabolites (DEQAS).

The assay of the intact PTH (hPTH 1-84) was performed with the "N-tact(R) PTH SP IRMA Kit" from DiaSorin. Bone mineral density at the lumbar spine and proximal 
femur was measured by dual-energy x-ray absorptiometry. The BMD of the two proximal femurs were assessed and the lowest femoral neck BMD was reported. A spine phantom was scanned each morning as a quality control and for instrument calibration.

\section{Statistical analysis}

The primary analysis has been performed in the whole study population and in three different categories of age (50-69 years, 70-79 years and 80 years and more). We also performed analysis according to the previous use of vitamin D supplements and we stratified our analysis according to the type of supplementation: patients without supplementation (group $1, \mathrm{n}=637$ ), patients receiving calcium alone (group 2, $\mathrm{n}=241$ ), patients with vitamin D but without calcium supplements (group 3, n =14), patients with calcium and vitamin D supplements (group 4, $\mathrm{n}=302$ ).

Analyses have been stratified according to sunlight exposure. In Belgium (50 degrees latitude North), spring is defined as March through June, summer as June through September, fall as September through December and winter as December though March.

Normality of variables has been confirmed by Kolmogorov-Smirnov tests. Student T tests were used to compare mean values of serum $25(\mathrm{OH}) \mathrm{D}$ in women with and without vitamin D supplement. ANOVA was performed to compare mean values of serum $25(\mathrm{OH}) \mathrm{D}$ and PTH according to the four groups of supplementation, age groups and seasons. Pairwise comparisons with adjustment for multiple comparisons (Bonferroni) were also made if the ANOVA was significant. Correlation coefficients were calculated to assess the relationship between the variables. All the data were analyzed using STATISTICA (version7.1; StatSoft Inc). P-values < 0.05 were regarded as significant.

\section{Results}

The 1195 women included in this study were aged (mean +/- SD) $76.9 \pm 7.5$ years. Their mean [SD] serum concentrations of $25(\mathrm{OH}) \mathrm{D}$, calcium, PTH were $52.5(21.4)$ $\mathrm{nmol} / \mathrm{L}, 2,37$ (0.12) $\mathrm{mmol} / \mathrm{L}$ and 31.2 (14.9) $\mathrm{pg} / \mathrm{mL}$, respectively. The characteristics of the study population are presented in Table 1.

In the whole study population, the lowest serum $25(\mathrm{OH}) \mathrm{D}$ concentrations $(<30 \mathrm{nmol} / \mathrm{L})$ were observed in $15.9 \%$ of all women. When considering the 50 and 80 $\mathrm{nmol} / \mathrm{L}$ cut-offs, the prevalence reaches $43.1 \%$ and $91.3 \%$, respectively.

The mean $[\mathrm{SD}]$ serum $25(\mathrm{OH}) \mathrm{D}$ concentrations reached 63 (20) nmol/L in women with vitamin D supplements compared to $48.7(20.7) \mathrm{nmol} / \mathrm{L}$ in women without vitamin D supplements $(P<0.001)$.

When stratified according to calcium and vitamin D supplementation, women who used vitamin D supplements, only or combined with calcium supplements, had higher concentrations of $25(\mathrm{OH}) \mathrm{D}$ than non-users : $59.3 \mathrm{nmol} /$ $\mathrm{L}$ (group 3) and $63.1 \mathrm{nmol} / \mathrm{L}$ (group 4) vs $45.9 \mathrm{nmol} / \mathrm{L}$ (group 1) and $56.4 \mathrm{nmol} / \mathrm{L}$ (group 2) $(P<0.001)$. The groups 1, 2 and 4 differ statistically with each other (Bonferroni correction $-P<0.001)$.

In groups receiving vitamin $\mathrm{D}$ supplements, severe $25(\mathrm{OH}) \mathrm{D}$ inadequacy $(<50 \mathrm{nmol} / \mathrm{L})$ was reported in $28.6 \%$ of the women. Mild and moderate inadequacy was reported by $85.7 \%$ and $82.8 \%$ of the women, respectively. In absence of vitamin D supplementations, $55.3 \%$ of the patients presented severe inadequacy and 96.2\% mild inadequacy (Figure 1).

There was a significant negative correlation between age and serum $25(\mathrm{OH}) \mathrm{D}(\mathrm{r}=-0.23 ; P<0.05)$. The mean serum 25(OH)D concentrations were $57.9 \mathrm{nmol} / \mathrm{L}$ in women aged less than 70 years old $(n=137)$. When considering patients aged more than 80 years $(n=430)$, $25(\mathrm{OH}) \mathrm{D}$ concentrations were $45.7 \mathrm{nmol} / \mathrm{L}$. In the intermediate group $(n=628)$, the mean concentrations of $25(\mathrm{OH}) \mathrm{D}$ were $56 \mathrm{nmol} / \mathrm{L}$. The vitamin $\mathrm{D}$ inadequacy was significantly higher in the oldest age group $(57.2 \%$ and $93.7 \%$ when considering cut-offs of 50 and $80 \mathrm{nmol} /$ $\mathrm{L}$, respectively) compared with the youngest age groups $(32.8 \%$ and $57.6 \%)(P<0.001)$. The youngest age groups differed statistically from the oldest age group (Bonferroni correction $-P<0.001$ ). (Figure 2)

A significant negative correlation was also found between serum 25(OH)D and PTH $(\mathrm{r}=-0.31 ; P<0.05$; figure 3$)$, serum PTH rising with age $(r=0.16 ; P<0.05)$. In figure 4 , comparing the effects of $25(\mathrm{OH}) \mathrm{D}$ concentrations and age on PTH, patients were grouped according to their age category and then further grouped, according to their $25(\mathrm{OH}) \mathrm{D}$ concentrations. For all age categories, there was a substantial and progressive decrease of PTH concentration as $25(\mathrm{OH}) \mathrm{D}$ increased. The lowest serum PTH concentrations were observed in the groups with serum 25hydroxyvitamin D concentrations of more than $80 \mathrm{nmol} /$ $\mathrm{L}$, whereas the highest serum PTH was observed in the groups with serum $25(\mathrm{OH}) \mathrm{D}$ concentrations lower than $50 \mathrm{nmol} / \mathrm{L}$. The PTH concentrations of the oldest group ( 80 years and more) were consistently higher than those of younger subjects. These differences are based on significant ANOVA and Bonferroni tests $(P<0.001)$. Furthermore, mean PTH concentrations were statistically different in each category of $25(\mathrm{OH}) \mathrm{D}$ concentrations (Bonferroni test $-P<0.05$ ) 
Table I: Baseline characteristics of the I I95 Belgian postmenopausal women.

\begin{tabular}{lll}
\hline & Mean \pm SD & Range \\
\hline Age (years) & $76.9 \pm 7.5$ & $50-100$ \\
Body mass index $\left(\mathrm{kg} / \mathrm{m}^{2}\right)$ & $25.7 \pm 4.5$ & $13.6-44.3$ \\
Lumbar bone mineral density $\left(\mathrm{g} / \mathrm{cm}^{2}\right)$ & $0.767 \pm 0.13$ & $0.387-1.357$ \\
Femoral neck bone mineral density $\left(\mathrm{g} / \mathrm{cm}^{2}\right)$ & $0.522 \pm 0.08$ & $0.211-0.953$ \\
Serum 25 -hydroxyvitamin $D(\mathrm{nmol} / \mathrm{L})$ & $52,5 \pm 21.4$ & $12.5-175$ \\
Serum Calcium (mmol/L) & $2,37 \pm 0.12$ & $1.93-2.85$ \\
Serum intact parathyroid hormone $(\mathrm{pg} / \mathrm{mL})$ & $31,2 \pm 14.9$ & $6-174.6$ \\
\hline
\end{tabular}

When stratified according to calcium and vitamin D supplementation, women who used vitamin D supplements, only or combined with calcium supplements, had lower PTH concentrations than non-users: $31.2 \mathrm{pg} / \mathrm{mL}$ (group 3) and $26.6 \mathrm{pg} / \mathrm{mL}$ (group 4) vs $34.2 \mathrm{pg} / \mathrm{mL}$ (group 1) and $30.2 \mathrm{nmol} / \mathrm{L}$ (group 2) $(P<0.001)$; although not reaching statistical significance after Bonferroni correction, between group 3 and the three other groups $(P<0.05)$.

A significant negative correlation between age, serum PTH and femoral neck BMD was found in the studied population $(\mathrm{r}=-0.29$ and $-0.15 ; P<0.05)$. We found also too a positive correlation between serum $25(\mathrm{OH}) \mathrm{D}$ and femo- ral neck BMD $(\mathrm{r}=0.07 ; P<0.05)$. Whereas no correlation between these variables (age, serum 25(OH)D and serum PTH) and BMD at lumbar spine was observed.

25(OH)D concentration did not vary with the season of sampling. Spring (March 20 - June 21) was characterized by lower concentrations of $25(\mathrm{OH}) \mathrm{D}(50.9 \mathrm{nmol} / \mathrm{L})$, while higher concentrations were observed in summer (June 21-September 23) $(55.1 \mathrm{nmol} / \mathrm{L})$. The prevalence of vitamin $\mathrm{D}$ severe inadequacy ( $50 \mathrm{nmol} / \mathrm{L}$ cut-off) during spring, summer, autumn and winter was $45.3 \%, 39.1 \%$, $44.5 \%$ and $43 \%$, respectively. However, these values did not reach statistical significance $(P=0.09)$. (Table 2 )

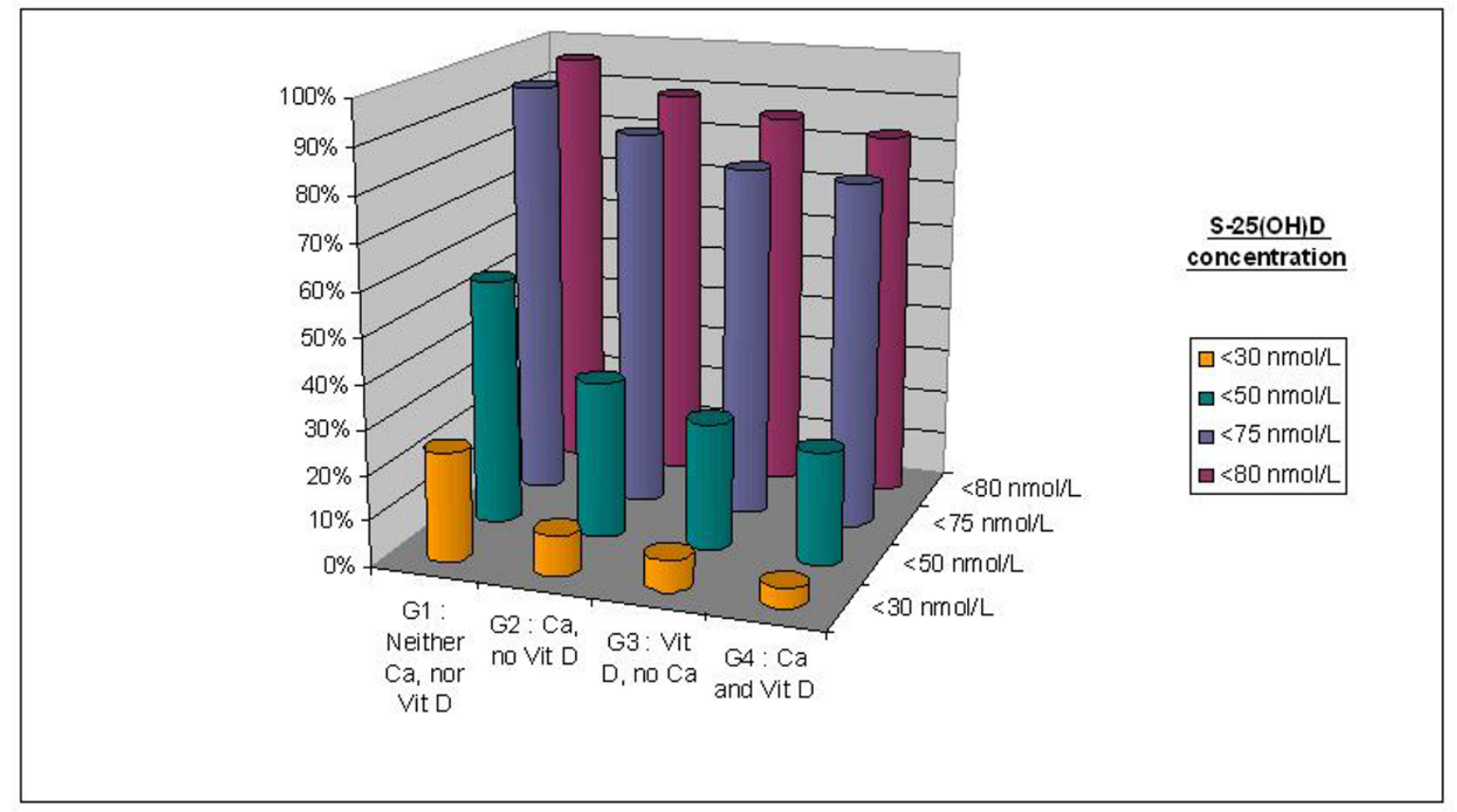

\section{Figure I}

Percentage of subjects having serum $25(\mathrm{OH}) \mathrm{D}$ concentration below various thresholds in the different groups stratified according to their type of supplementation. 


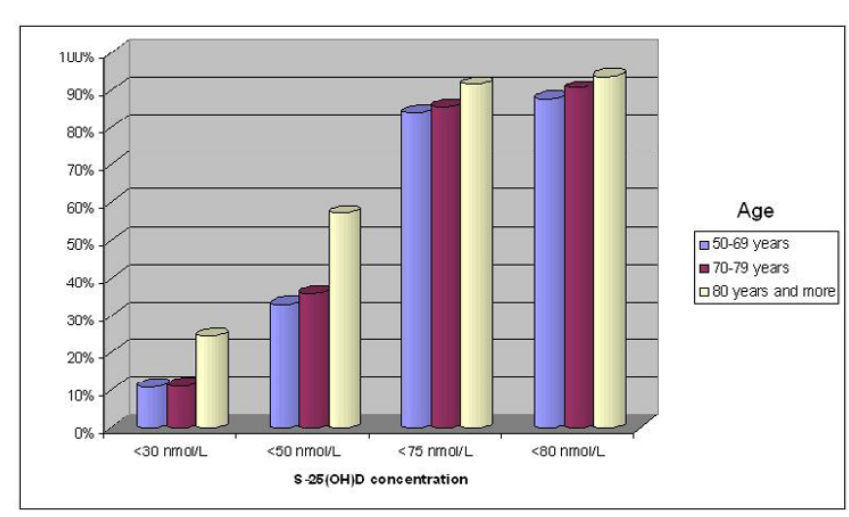

Figure 2

Effect of age on prevalence of vitamin D inadequacy.

\section{Discussion}

The results of this study show a high prevalence of vitamin $\mathrm{D}$ inadequacy amongst Belgian postmenopausal women, irrespective of the threshold used for the diagnosis.

The serum concentrations of $25(\mathrm{OH}) \mathrm{D}$ are most valuable for determining the overall vitamin D status of an individual, since it is an average of dietary and sunlight-induced vitamin $\mathrm{D}$. The measurement of the serum 1,25(OH)2D concentrations has been most useful in evaluating disorders in calcium and bone metabolism related to acquired and inborn errors in the conversion of $25(\mathrm{OH}) \mathrm{D}$ to $1,25(\mathrm{OH}) 2 \mathrm{D}[16-18]$.

Assessment of 25-hydroxyvitamin D [25(OH)D] was performed with a commercial radioimmunoassay (DiaSorin). It is important to specify that interlaboratory variability in serum 25-hydroxyvitamin D (25(OH)D) results is often reported because of the use of different methodologies (protein binding, chemiluminescent and RIA assays). This variation in measurement confounds the diagnosis of vitamin D insufficiency. Consequently, these assays must be internationally standardized and made available to practicing clinicians [19]. From this perspective, the International Quality Assessment Scheme for Vitamin D metabolites (DEQAS) was introduced in 1989 to improve the reliability of 25-hydroxyvitamin D (25OHD) assays [20].

No universal consensus has been reached regarding serum values constitutive of inadequacy. Indeed, the vitamin D status that fully normalizes calcium absorption is not known for humans [3]. Recent publications suggest that the circulating concentration of $25(\mathrm{OH}) \mathrm{D}$ should be over $80 \mathrm{nmol} / \mathrm{L}$ or at least between $50 \mathrm{nmol} / \mathrm{L}$ and $80 \mathrm{nmol} / \mathrm{L}$ to optimize intestinal calcium absorption, minimize increased parathyroid activity and reduce the risk of hip and other non vertebral fractures $[21,22]$. It has been demonstrated that calcium absorption is reduced in patients with $25(\mathrm{OH}) \mathrm{D}$ concentrations below $80 \mathrm{nmol} / \mathrm{L}$ corresponding to higher PTH secretion (reported at 25(OH)D values below $80 \mathrm{nmol} / \mathrm{L}$ ) [3]. In this particular study, two cut-offs of 25(OH)D inadequacy were fixed : < $80 \mathrm{nmol} / \mathrm{L}$ and $<50 \mathrm{nmol} / \mathrm{L}$. However, we also used the threshold of $75 \mathrm{nmol} / \mathrm{l}$, suggested by a consensus expert panel and a review [22,23] and a concentration of 30 $\mathrm{nmol} / \mathrm{L}$, considered by certain authors as the lower limit indicating a severe deficiency [24-27].

Various studies found that postmenopausal women who have osteoporosis (involving low bone mineral density and/or history of fragility fracture) are more likely to have serum vitamin $\mathrm{D}$ concentrations below the normal range. For example, in United Kingdom, in 330 patients with fragility fractures from Glasgow, Belfast and Medway, mean concentrations of $25(\mathrm{OH}) \mathrm{D}$ ranged from $40 \mathrm{nmol} / \mathrm{L}$ to $52.3 \mathrm{nmol} / \mathrm{L}$ and 83.7 to $96.4 \%$ of patients had 25hydroxyvitamin D concentrations $<80 \mathrm{nmol} / \mathrm{L}$ and 55.8 to $73.2 \%<50 \mathrm{nmol} / \mathrm{L}$. 694 patients with hip fractures were specially identified from Belfast, Glasgow and London. Their mean concentrations of $25(\mathrm{OH}) \mathrm{D}$ ranged from $24.7 \mathrm{nmol} / \mathrm{L}$ to $36.1 \mathrm{nmol} / \mathrm{L}$ and 81.6 to $92.7 \%$ had a concentration $<50 \mathrm{nmol} / \mathrm{L}$ [28]. In a systematic review of 30 publications reporting prevalence estimates for vitamin D inadequacy in populations with osteoporosis associated with other disorders possibly, the prevalence of $25(\mathrm{OH}) \mathrm{D}$ concentrations $<12 \mathrm{ng} / \mathrm{mL}$ (30 nmol/L) ranged from $12.5 \%$ to $76 \%$, while prevalence rates reached $50 \%$ to $70 \%$ of patients with a history of fracture(s) using a cut-off of $15 \mathrm{ng} / \mathrm{mL}$ [29].

However, the prevalence observed in our cohort of osteoporotic postmenopausal women is generally lower than previously reported in elderly subjects in previous studies and in healthy adults [30]. The women enrolled in our study were fairly healthy, free of diseases other than osteoporosis. In addition, volunteers for clinical trials may be more conscious about their health than the general population. All these factors may have contributed to the lower overall prevalence of vitamin $\mathrm{D}$ deficiency observed in this study compared with previous studies. Same observations have been reported in two recent studies. In a multinational study of 18 countries, the mean serum $25(\mathrm{OH}) \mathrm{D}$ concentrations of 2606 osteoporotic postmenopausal women were $26.8 \mathrm{ng} / \mathrm{mL}(67 \mathrm{nmol} / \mathrm{L})$ with an average serum 25(OH)D of $29.3 \mathrm{ng} / \mathrm{mL}$ (73.2 nmol/L) in Europe. Overall, $64 \%$ of patients had serum concentrations $<30$ $\mathrm{ng} / \mathrm{mL}(75 \mathrm{nmol} / \mathrm{L})$ and women receiving pharmacological treatment for osteoporosis had mean concentrations similar to those recorded in women who were not receiving such treatment [31]. In the Multiple Outcomes of Raloxifene Evaluation study, a large prospective intervention trial in postmenopausal women with osteoporosis, 


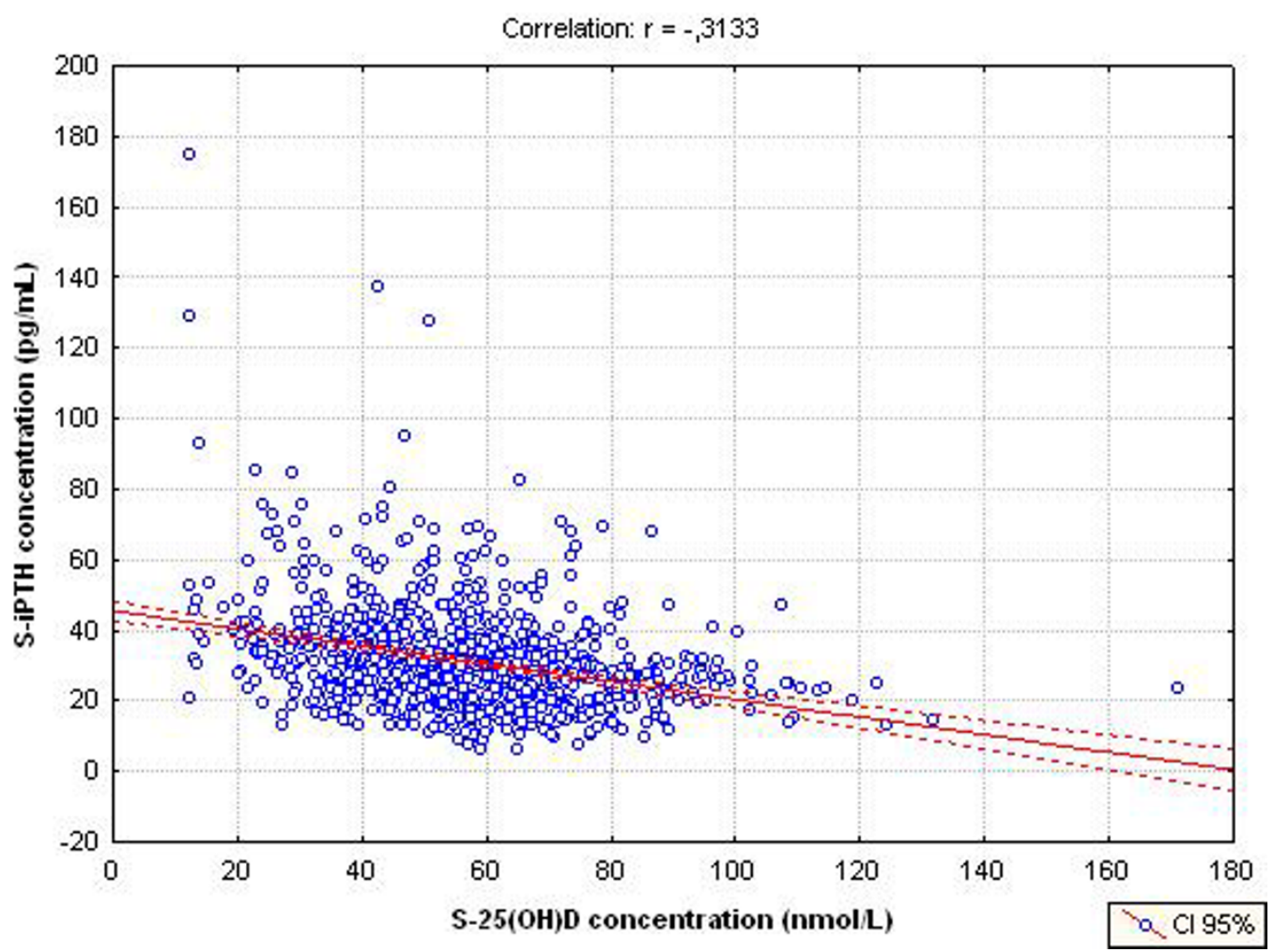

Figure 3

Plot of serum intact PTH concentrations versus serum $25(\mathrm{OH}) \mathrm{D}$ concentrations.

the mean serum $25(\mathrm{OH}) \mathrm{D}$ concentrations of the whole study population $(\mathrm{n}=7564)$ were $70.8 \mathrm{nmol} / \mathrm{L}(65.9$ $\mathrm{nmol} / \mathrm{L}$ in Central Europe). Low serum 25(OH)D $(<50$ $\mathrm{nmol} / \mathrm{L})$ were observed in $39 \%$ of the women living in Central Europe [32].

We also show that the prevalence of vitamin $\mathrm{D}$ inadequacy remains major, even amongst subjects receiving vitamin D supplements, with or without calcium. One could wonder if the supplementations are really appropriate to the individual needs in postmenopausal osteoporotic women although we have no data on the doses and length of supplementation used and the compliance of the subjects.

In our cohort, we observe a significant correlation between age and vitamin D [25(OH)D] concentrations. These results seem to be in accordance with previous studies, showing a highest prevalence of vitamin D deficiency in the oldest population varying from $5-25 \%$ in independent elderly to $60-80 \%$ in institutionalized elderly $[32,33]$. It has been shown that there is an age-dependent decrease in the epidermal concentrations of provitamin D3 (7-dehydrocholesterol) that explains the growing incapacity of human skin to produce vitamin D3 [10]. In elderly, kidneys are less effective to hydroxylate vitamin D to form 1,25-dihydroxyvitamin D (1,25(OH)2D3) [34]. Furthermore, there is a defect in intestinal absorption of cholecalciferol in the elderly, after oral ingestion [35]. In

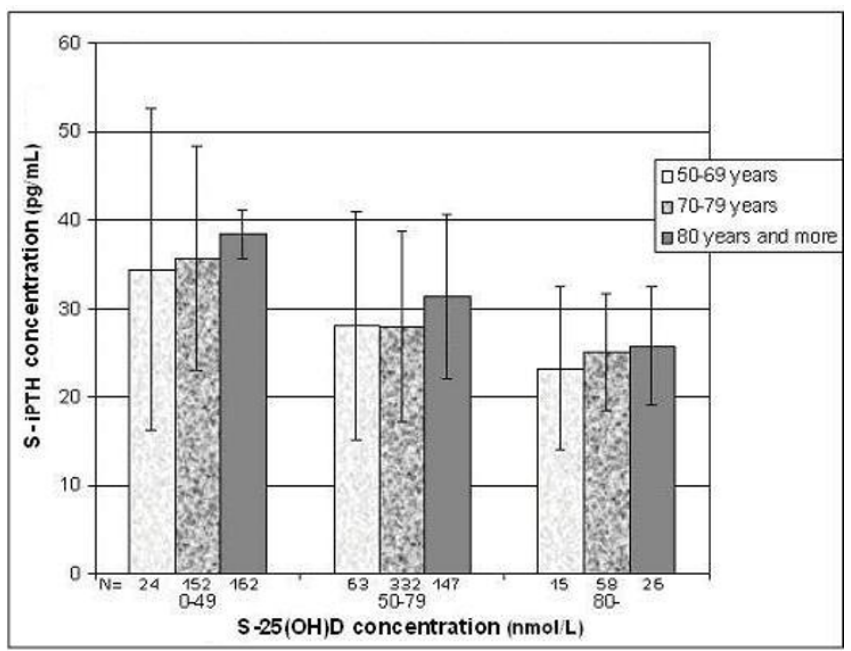

Figure 4

Adjusted mean serum parathyroid hormone values according to serum 25-hydroxyvitamin D values and age group. 
Table 2: Prevalence of vitamin D inadequacy stratified for seasons.

\begin{tabular}{lllll}
\hline & I. Spring & 2. Summer & 3 . Fall & 4. Winter \\
\hline$<30 \mathrm{nmol} / \mathrm{L}$ & $15,3 \%$ & $9,9 \%$ & $17,5 \%$ & $20,9 \%$ \\
$<50 \mathrm{nmol} / \mathrm{L}$ & $45,3 \%$ & $39,1 \%$ & $44,5 \%$ & $43,0 \%$ \\
$<75 \mathrm{nmol} / \mathrm{L}$ & $90,8 \%$ & $86,9 \%$ & $85,3 \%$ & $85,4 \%$ \\
$<80 \mathrm{nmol} / \mathrm{L}$ & $93,6 \%$ & $89,4 \%$ & $91,0 \%$ & $90,2 \%$ \\
\hline
\end{tabular}

the same way, a late age-related decrease in calcium absorption is seen in postmenopausal women, in addition to the decline that occurs at menopause. This decrease could be due to a decline in either the active calcium transport or diffusion component of the calcium absorption system [36]. Moreover, in elderly, a depletion of body vitamin $\mathrm{D}$ stores results from a lack of sun exposure, due to progressive disability with age and subsequent the tendency to stay indoors, low dietary intake and reduced ability to adapt to a low calcium diet. This contributes to a higher prevalence of vitamin D inadequacy [34,37].

The combined deficiency in calcium and vitamin $\mathrm{D}$, widespread in the ageing population, stimulates the secretion of parathyroid hormone which tends to normalize serum calcium concentrations, contributes to accelerated bone loss and plays a central role in pathogenesis of bone disorders and osteoporosis in the elderly [38]. Concomitantly, a decrease in bone strength and loss of muscle mass occurs.

Consistent with other reports, we find an inverse correlation between 25(OH)D and PTH, and a PTH rise with age $[32,39,40]$. In addition, 25(OH)D concentrations were positively correlated with hip BMD, similar to other studies of Caucasian postmenopausal women. The negative correlation of PTH concentrations with femoral neck BMD is also in accordance with other studies. [33,39,4143]

In our study, we also show a difference in vitamin $\mathrm{D}$ [25(OH)D] concentrations between seasons, the lowest concentrations being seen during the spring months and the highest during the summer months. However, this difference is not statistically significant. These findings are in accordance with previous studies, especially with a similar study done in another European country [44]. In our study, it should be pointed that vitamin D inadequacy is high (over $89 \%$ with the $80 \mathrm{nmol} / \mathrm{L}$ cut-off) even during summer. These results suggest that vitamin D supplement may be requested in osteoporotic postmenopausal women, independently of the season.

Many studies have demonstrated the effectiveness of calcium and vitamin D supplementation in fracture preven- tion particularly in patients with appropriate adherence to treatment. However, effectiveness of vitamin D alone in fracture prevention is still debated [45-52]. Calcium and vitamin $\mathrm{D}$ have been shown to reverse secondary hyperparathyroidism with resulting beneficial effects on bone mineral density (BMD)[37]. Additionally, it has been shown that calcium and vitamin D supplementation significantly improve body sway, muscle function and lower extremity strength, as well as reduce the risk of falls [53$55]$.

There is general agreement that adequate vitamin D and calcium intake is the cornerstone of osteoporosis prevention. In patients with documented osteoporosis, calcium and vitamin $\mathrm{D}$ supplementation should be a first line component of the osteoporosis care, along with antiresorptive or anabolic treatment [53].

\section{Conclusion}

This study points out a high prevalence of vitamin D inadequacy in Belgian postmenopausal osteoporotic women even among subjects receiving vitamin D supplements. More studies are needed to address the amount of vitamin D intake necessary to maintain serum $25(\mathrm{OH}) \mathrm{D}$ to an adequate concentration which prevents secondary hyperparathyroidism and minimizes the possibility of further bone loss.

\section{Competing interests}

The author(s) declare that they have no competing interests.

\section{Authors' contributions}

AN and OB performed the statistical analysis, analyzed and interpreted the data. They drafted the manuscript. JYR revised it critically for important intellectual content. OB and JYR conceived of the study and participated in the design and coordination. All authors read and approved the final manuscript. JC performed the assays and critically analysed the screen samples.

\section{Acknowledgements}

The authors thank Servier that give their database. 


\section{References}

I. Assessment of fracture risk and its application to screening for postmenopausal osteoporosis. Report of a WHO Study Group. World Health Organ Tech Rep Ser 1994, 843: I-I 29.

2. Norman AW: Sunlight, season, skin pigmentation, vitamin $D$, and 25-hydroxyvitamin D: integral components of the vitamin D endocrine system. Am J Clin Nutr 1998, 67(6): I I08-I I I0.

3. Heaney RP, Dowell MS, Hale CA, Bendich A: Calcium absorption varies within the reference range for serum 25-hydroxyvitamin D. J Am Coll Nutr 2003, 22(2): | $42-146$.

4. Holick MF: High prevalence of vitamin $D$ inadequacy and implications for health. Mayo Clin Proc 2006, 8 I (3):353-373.

5. Reginster JY: The high prevalence of inadequate serum vitamin D levels and implications for bone health. Curr Med Res Opin 2005, 2 I (4):579-586.

6. Melton LJ 3rd, Atkinson EJ, O'Fallon WM, Wahner HW, Riggs BL: Long-term fracture prediction by bone mineral assessed at different skeletal sites. J Bone Miner Res I993, 8(1 0): I 227-I 233.

7. Bischoff-Ferrari HA, Dietrich T, Orav El, Hu FB, Zhang Y, Karlson EW, Dawson-Hughes B: Higher 25-hydroxyvitamin D concentrations are associated with better lower-extremity function in both active and inactive persons aged $>$ or $=60 \mathrm{y} . \mathrm{Am} \mathrm{J} \mathrm{Clin}$ Nutr 2004, 80(3):752-758.

8. Bischoff-Ferrari HA, Conzelmann M, Dick W, Theiler R, Stahelin HB: [Effect of vitamin $D$ on muscle strength and relevance in regard to osteoporosis prevention]. Z Rheumatol 2003 , 62(6):5|8-52|.

9. Flicker L, Mead K, Maclnnis RJ, Nowson C, Scherer S, Stein MS, Thomasx J, Hopper JL, Wark JD: Serum vitamin D and falls in older women in residential care in Australia. I Am Geriatr Soc 2003 5 I (I I): I533-I538.

10. MacLaughlin J, Holick MF: Aging decreases the capacity of human skin to produce vitamin D3. I Clin Invest 1985, 76(4): $1536-1538$.

II. Holick MF, Matsuoka LY, Wortsman J: Age, vitamin D, and solar ultraviolet. Lancet I989, 2(867 I): | |04- I 105.

12. Holick MF: Environmental factors that influence the cutaneous production of vitamin D. Am J Clin Nutr 1995, 6I(3 Suppl):638S-645S.

13. Fassbender W], Stumpf UC, Jockenhovel F: [Pharmacotherapy of osteoporosis: evidence-based clinical practice]. Med Klin (Munich) 2006, I 0 I Suppl I:I73-I77.

14. Boonen S, Body J, Boutsen Y, Devogelaer JP, Goemaere S, Kaufman JM, Rozenberg S, Reginster JY: Evidence-based guidelines for the treatment of postmenopausal osteoporosis: a consensus document of the Belgian Bone Club. Osteoporos Int 2005, I 6(3):239-254.

15. Compston J: Guidelines for the management of osteoporosis: the present and the future. Osteoporos Int 2005, I 6(10): I I73-II76.

16. Holick MF: The role of vitamin $D$ for bone health and fracture prevention. Curr Osteoporos Rep 2006, 4(3):96-102.

17. Holick MF: The use and interpretation of assays for vitamin D and its metabolites. J Nutr 1990, I 20 SuppI I I:| 464-| 469.

18. Holick MF: Evolution and function of vitamin D. Recent Results Cancer Res 2003, 164:3-28.

19. Binkley N, Krueger D, Cowgill CS, Plum L, Lake E, Hansen KE, DeLuca HF, Drezner MK: Assay variation confounds the diagnosis of hypovitaminosis D: a call for standardization. J Clin Endocrinol Metab 2004, 89(7):3।52-3I57.

20. Carter GD, Carter CR, Gunter E, Jones J, Jones G, Makin HL, Sufi S: Measurement of Vitamin D metabolites: an internationa perspective on methodology and clinical interpretation. J Steroid Biochem Mol Biol 2004, 89-90( I-5):467-47I.

21. Heaney RP: The Vitamin D requirement in health and disease. J Steroid Biochem Mol Biol 2005, 97( I-2): I3-19.

22. Dawson-Hughes B, Heaney RP, Holick MF, Lips P, Meunier PJ, Vieth R: Estimates of optimal vitamin D status. Osteoporos Int 2005, I 6(7):7|3-7|6.

23. Bischoff-Ferrari HA, Giovannucci E, Willett WC, Dietrich T, DawsonHughes B: Estimation of optimal serum concentrations of 25hydroxyvitamin $\mathbf{D}$ for multiple health outcomes. Am J Clin Nutr 2006, 84(I): 18-28.

24. Chapuy MC, Preziosi P, Maamer M, Arnaud S, Galan P, Hercberg S, Meunier PJ: Prevalence of vitamin $D$ insufficiency in an adult normal population. Osteoporos Int 1997, 7(5):439-443.
25. Muscarella S, Filabozzi P, D'Amico G, Mascia ML, Annese MA, Scillitani $A$, Carnevale V: Vitamin D status in inpatients admitted to an internal medicine department. Horm Res 2006, 66(5):216-220.

26. Lips $P$, Wiersinga A, van Ginkel FC, Jongen MJ, Netelenbos JC, Hackeng WH, Delmas PD, van der Vijgh WJ: The effect of vitamin D supplementation on vitamin $D$ status and parathyroid function in elderly subjects. J Clin Endocrinol Metab 1988 , 67(4):644-650.

27. Souberbielle JC, Cormier C, Kindermans C, Gao P, Cantor T, Forette $F$, Baulieu EE: Vitamin D status and redefining serum parathyroid hormone reference range in the elderly. J Clin Endocrinol Metab 200I, 86(7):3086-3090.

28. Dixon T, Mitchell P, Beringer T, Gallacher S, Moniz C, Patel S, Pearson $G$, Ryan P: An overview of the prevalence of 25-hydroxy-vitamin $D$ inadequacy amongst elderly patients with or without fragility fracture in the United Kingdom. Curr Med Res Opin 2006, 22(2):405-4I5.

29. Gaugris S, Heaney RP, Boonen S, Kurth H, Bentkover JD, Sen SS: Vitamin $D$ inadequacy among post-menopausal women: a systematic review. Qjm 2005, 98(9):667-676.

30. Lamberg-Allardt CJ, Outila TA, Karkkainen MU, Rita HJ, Valsta LM: Vitamin $D$ deficiency and bone health in healthy adults in Finland: could this be a concern in other parts of Europe? J Bone Miner Res 200 I, I 6(I I ):2066-2073.

31. Lips P, Hosking D, Lippuner K, Norquist JM, Wehren L, Maalouf G, Ragi-Eis $S$, Chandler J: The prevalence of vitamin $D$ inadequacy amongst women with osteoporosis: an international epidemiological investigation. J Intern Med 2006, 260(3):245-254.

32. Lips P, Duong T, Oleksik A, Black D, Cummings S, Cox D, Nickelsen $T$ : A global study of vitamin $D$ status and parathyroid function in postmenopausal women with osteoporosis: baseline data from the multiple outcomes of raloxifene evaluation clinical trial. J Clin Endocrinol Metab 200I, 86(3):|2|2-|22|.

33. Reginster JY, Deroisy R, Pirenne H, Frederick I, Dewe W, Albert A, Collette J, Zheng SX, Gosset C: High prevalence of low femoral bone mineral density in elderly women living in nursing homes or community-dwelling: a plausible role of increased parathyroid hormone secretion. Osteoporos Int 1999, 9(2): $|2|-\mid 28$

34. Bouillon R, Carmeliet G, Boonen S: Ageing and calcium metabolism. Baillieres Clin Endocrinol Metab 1997, I I (2):34 I-365.

35. Barragry JM, France MW, Corless D, Gupta SP, Switala S, Boucher B], Cohen RD: Intestinal cholecalciferol absorption in the elderly and in younger adults. Clin Sci Mol Med I 978, 55(2):21 3-220.

36. Nordin BE, Need AG, Morris HA, O'Loughlin PD, Horowitz M Effect of age on calcium absorption in postmenopausal women. Am J Clin Nutr 2004, 80(4):998-1002.

37. Lips P: Vitamin D deficiency and secondary hyperparathyroidism in the elderly: consequences for bone loss and fractures and therapeutic implications. Endocr $\operatorname{Rev} 2001$, 22(4):477-50I.

38. Benhamou CL, Tourliere D, Asselin F: [Influence of aging on vitamin D metabolism]. Rev Rhum Ed Fr 1993, 60(6):445-449.

39. von Muhlen DG, Greendale GA, Garland CF, Wan L, Barrett-Connor $E:$ Vitamin D, parathyroid hormone levels and bone mineral density in community-dwelling older women: the Rancho Bernardo Study. Osteoporos Int 2005, I 6( I 2): I 72 I-I 726.

40. Reginster JY, Frederick I, Deroisy R, Dewe W, Taquet AN, Albert A, Collette J, Pirenne H, Zheng SX, Gosset C: Parathyroid hormone plasma concentrations in response to low 25-OH vitamin D circulating levels increases with age in elderly women. Osteoporos Int 1998, 8(4):390-392.

41. Malavolta N, Pratelli L, Frigato M, Mule R, Mascia ML, Gnudi S: The relationship of vitamin $\mathrm{D}$ status to bone mineral density in an Italian population of postmenopausal women. Osteoporos Int 2005, I 6( I 2): 1691-1697.

42. Bischoff-Ferrari HA, Dietrich T, Orav EJ, Dawson-Hughes B: Positive association between 25-hydroxy vitamin $D$ levels and bone mineral density: a population-based study of younger and older adults. Am J Med 2004, I I 6(9):634-639.

43. Sigurdsson G, Franzson L, Steingrimsdottir L, Sigvaldason H: The association between parathyroid hormone, vitamin $D$ and bone mineral density in 70-year-old Icelandic women. Osteoporos Int 2000, I I ( I 2): I 03 I-1035.

44. Bhattoa HP, Bettembuk P, Ganacharya S, Balogh A: Prevalence and seasonal variation of hypovitaminosis $D$ and its relationship 
to bone metabolism in community dwelling postmenopausal Hungarian women. Osteoporos Int 2004, I 5(6):447-45I.

45. Avenell A, Gillespie WJ, Gillespie LD, O'Connell DL: Vitamin D and vitamin $D$ analogues for preventing fractures associated with involutional and post-menopausal osteoporosis. Cochrane Database Syst Rev 2005:CD000227.

46. Dawson-Hughes B, Harris SS, Krall EA, Dallal GE: Effect of calcium and vitamin $D$ supplementation on bone density in men and women 65 years of age or older. N Engl J Med 1997, 337( 10$)$ :670-676.

47. Bischoff-Ferrari HA, Dawson-Hughes B, Willett WC, Staehelin HB, Bazemore MG, Zee RY, Wong JB: Effect of Vitamin D on falls: a meta-analysis. Jama 2004, 29 I(16): 1999-2006.

48. Bischoff-Ferrari HA, Willett WC, Wong JB, Giovannucci E, Dietrich $T$, Dawson-Hughes B: Fracture prevention with vitamin D supplementation: a meta-analysis of randomized controlled trials. Jama 2005, 293( I 8):2257-2264.

49. Di Daniele N, Carbonelli MG, Candeloro N, lacopino L, De Lorenzo $A$, Andreoli A: Effect of supplementation of calcium and vitamin $D$ on bone mineral density and bone mineral content in peri- and post-menopause women; a double-blind, randomized, controlled trial. Pharmacol Res 2004, 50(6):637-64I.

50. Chapuy MC, Arlot ME, Duboeuf F, Brun J, Crouzet B, Arnaud S, Delmas PD, Meunier PJ: Vitamin D3 and calcium to prevent hip fractures in the elderly women. N Engl J Med 1992, 327(23): 1637-1642.

5I. Prince RL, Devine A, Dhaliwal SS, Dick IM: Effects of calcium supplementation on clinical fracture and bone structure: results of a 5-year, double-blind, placebo-controlled trial in elderly women. Arch Intern Med 2006, I 66(8):869-875.

52. Jackson RD, LaCroix AZ, Gass M, Wallace RB, Robbins J, Lewis CE, Bassford T, Beresford SA, Black HR, Blanchette P, Bonds DE, Brunner RL, Brzyski RG, Caan B, Cauley JA, Chlebowski RT, Cummings SR, Granek I, Hays J, Heiss G, Hendrix SL, Howard BV, Hsia J, Hubbell FA, Johnson KC, Judd H, Kotchen JM, Kuller LH, Langer RD, Lasser NL, Limacher MC, Ludlam S, Manson JE, Margolis KL, McGowan J, Ockene JK, O'Sullivan MJ, Phillips L, Prentice RL, Sarto GE, Stefanick ML, Van Horn L, Wactawski-Wende J, Whitlock E, Anderson GL, Assaf AR, Barad D: Calcium plus vitamin D supplementation and the risk of fractures. N Engl J Med 2006, 354(7):669-683.

53. Boonen S, Bischoff-Ferrari HA, Cooper C, Lips $P$, Ljunggren $O$, Meunier PJ, Reginster JY: Addressing the musculoskeletal components of fracture risk with calcium and vitamin $D$ : a review of the evidence. Calcif Tissue Int 2006, 78(5):257-270.

54. Okuizumi $\mathrm{H}$, Harada A: [Effect of vitamin $\mathbf{D}$ on bone mineral density; bone strength and fracture prevention]. Clin Calcium 2006, I6(7):3I-37.

55. Hayashi Y: [Active vitamin D metabolite and prevention of falls]. Clin Calcium 2005, 15(4):655-660.

\section{Pre-publication history}

The pre-publication history for this paper can be accessed here:

http://www.biomedcentral.com/1471-2458/7/64/prepub

\section{Publish with Bio Med Central and every scientist can read your work free of charge}

"BioMed Central will be the most significant development for disseminating the results of biomedical research in our lifetime. "

Sir Paul Nurse, Cancer Research UK

Your research papers will be:

- available free of charge to the entire biomedical community

- peer reviewed and published immediately upon acceptance

- cited in PubMed and archived on PubMed Central

- yours - you keep the copyright
BioMedcentral 